\title{
READERS
nsight
}

Journal of Research in Psychology

www.readersinsight.net/jrp

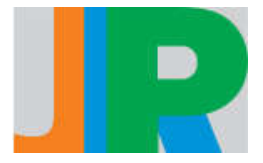

\section{The Influence of Emotional Labour Strategies on Psychological Well- being with Job Tenure as Moderator: A Systematic Literature Review}

\author{
Joshua Tan Jia Hong ${ }^{1 \star}$, Siti Aisyah Panatik ${ }^{1}$ \\ ${ }^{1}$ School of Human Resource Development and Psychology, Faculty of Social Sciences and Humanities, Universiti Teknologi Malaysia \\ ${ }^{*}$ Corresponding author: joshua.tan.0831@gmail.com

\begin{abstract}
This paper aim to present the finding of emotional labour strategies on psychological well-being based on previous scholars. Additional finding of demographic variable in relation to emotional labour was included as well. The paper has further introduced the methodologies which are search strategy, inclusion and exclusion criteria, selection strategy and data analysis. The paper has concluded a sample of 35 articles was included in this study. As reflection to the present study, numerous article which finding is focus on association between emotional labour and well-being of employees, and linkage between emotional labour and demographic profiles were included. The discussion section has included numerous finding that the finding is focusing on emotional labour and psychological well-being, emotional labour and demographic variables, and a research gap which indicate the needs of the present study. A description of limitation for constructing this paper was included which consists from numerous limitation issues during the writing of
\end{abstract} \\ paper. Finally, a conclusion was included as the ending of this paper.
}

ARTICLE INFORMATION

Received: 6-May-2019

Revised: 13-Jul-2019

Accepted: 10-Aug-2019

(C) Readers Insight Publication

Keywords: emotional labour, employee well-being, job tenure

\section{INTRODUCTION}

In today society, well-being has become one of the common topics, regardless of industry or group of people. Organizations are concerned about the well-being of employees as it brings significant outcomes to employees such as performance, turnover, satisfaction and so on. According to the study of Jayasinghe (2017), majority of adult spends approximate two third (2/3) of life in working. Thus, employee's wellbeing become of the concern for organization and society as the main objective of organization is to maximize the profitability which wellbeing of employees will be one of the concerns.

In the study of Savoie (2012), psychological health of employees become of the issues that employers concerned and worried. The study further justified around 36 million workers in United Stated paid huge amount of money (cost $\$ 57.5$ billion) for mental health services. Based on the finding of Jayasinghe (2017), a study of employee's at hotel industry was done and the researcher had identified the well-being of the selected sample (front-line employees) has been categorized into different levels:

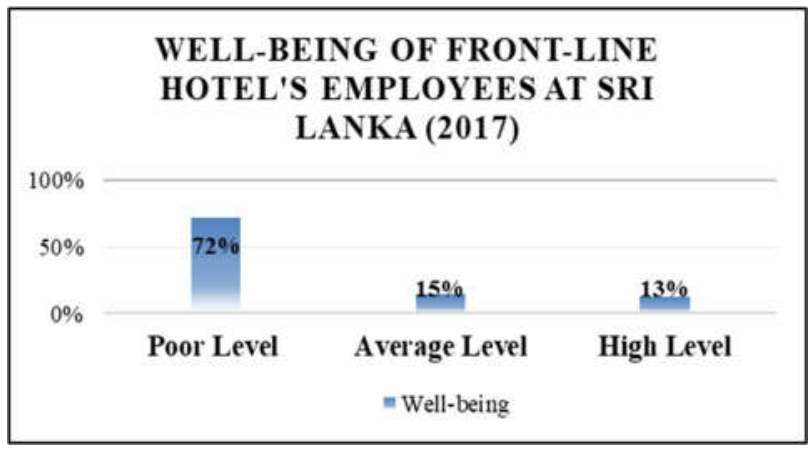

Fig. 1: Well-being study among hotel's employee Jayasinghe (2017)

The study in Fig. 1 showed front-line employees from hotel industry, who usually have higher interaction with clients or guest tends to result in poor well-being due to resources like emotional engagement with clients in order to meet their expectation. Thus, the findings indicate such issue need to be minimize. In order to align with the present study, the researcher also identified the finding from previous scholars mentioned the importance of well-being for instance in academia (Panatik et al., 2012). The study has specifically studied the job satisfaction and turnover intention which are considered as category of well-being. The finding has shown that numerous factors (i.e. job 
control, job demand, violence relationship) impact to well-being of academician. However, there is external factor such as emotional labour being found in the study. Therefore, this study aims to investigate through systematic literature review on how the emotional strategies (i.e. surface acting, deep acting, genuine acting) influence the well-being. In addition to explore the moderator effects of job tenure.

\section{LITERATURE REVIEW}

\section{Concept and study of Psychological Well-Being}

Various studies have showed the concept of psychological wellbeing in different ways. Study of Savoie (2012) provide the concept of psychological well-being that refers to individual's experience at work that are based on five (5) dimensions namely, "interpersonal fit at work", "thriving at work", "feelings of competency at work", "perceived recognition at work", and "desire involvement at work". On the other word, psychological well-being can be defined as personal's experience towards the achievement and recognition, mental health, satisfaction, purpose of life and social relationship. According to the study of Vermaak, Görgens-ekermans, \& Nieuwenhuize (2017), psychological well-being at work is significant for employee's retention and satisfaction. Besides, psychological well-being also result in outcome such as employee's performance (Peiro, Tordera, \& Lorente, 2014). The study has further designed a model to identify the connection among the level of well-being and performance. Following shows the Fig.:

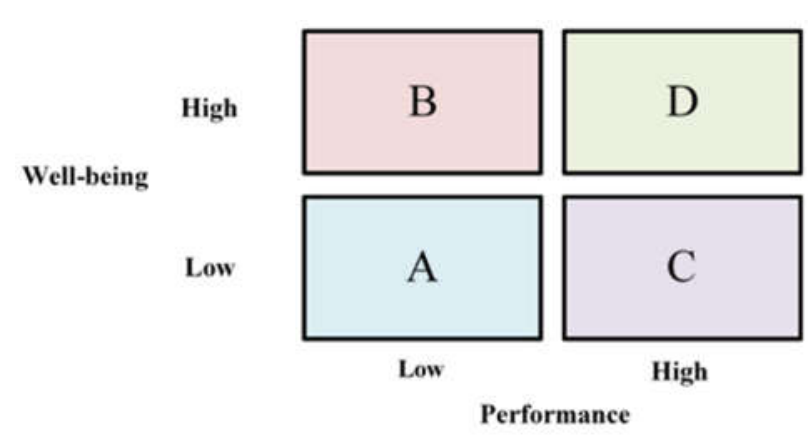

Fig. 2: Effect between well-being and performance of employees (Peiro et al., 2014)

Fig. 2 shows the interaction between well-being and performance. The situation inside each box, A, B, C and D indicate relationship between variables of well-being and performance. For instance, employees in situation A who are with poor well-being result in poor performance. Study identified the connection between good life and psychological well-being (Dierendonck, Di'az, Amalio, Rodri'guezCarvajal, \& Moreno-Jime'nez, 2007). The study also identified a six (6) factors model falls under psychological well-being which was developed by Ryff and Singer in year of 2006: "Autonomy", "Selfacceptance", "Positive relations", "Environmental mastery", "Purpose in life", "Personal growth". In the present study, the researcher will use psychological well-being at work as an outcome measurement which is the dependent variable. On the other hand, study of Page \& Vella-brodrick (2014) also justified employee's mental health are categorized from three (3) well-being areas based on the previous scholars. Fig. 3 on the following page represent the areas of employee well-being by the author.

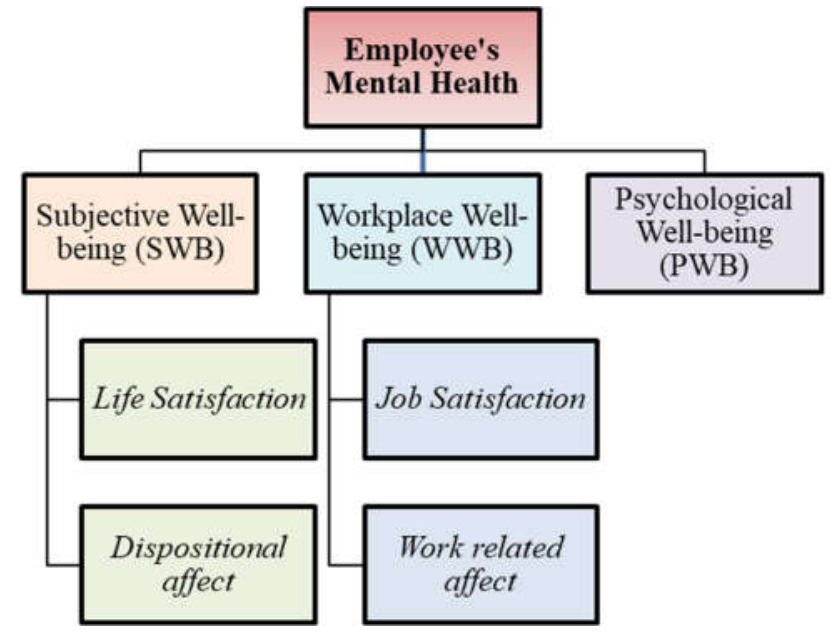

Fig. 3: Employee's Mental Health Category by Page \& Vella-brodrick (2014)

\section{Concept and study of Emotional Labour}

Jayasinghe (2017) has introduce the definition of emotional labour by Morris \& Feldman in 1996 which is "the effort, planning, and control needed to express organizationally desired emotion during interpersonal transactions". On the other word, emotional labour is a concept whereby employees display his or her emotions and feeling as accordance to the requirements of jobs and organization. According to study of Zapf (2018), emotional labor (EL) is a concept introduced by Hochschild in year of 1979. Hochschild had investigated towards the sample group of flight attendants. She justified the work of flight attendants shall not be solely based on physical services, but a consideration of emotions practices also. Another similar term of emotional labor refers to emotional work. Generally, emotional labor is significant among employees who are with high interaction of clients. The effort of emotional labor performed by service provider are through two (2) strategies, namely surface acting \& deep acting. According to the research of Jayasinghe (2017), there was a third emotional labor strategies being introduced by Ashforth and Humphrey in 1993, namely genuine emotional labor. The study further discussed utilization of emotional labour should be highly expected from frontline workers from hotel industry due to high interaction with guest. Front-line workers who are highly engaged in emotional labor will achieved higher customer satisfaction.

In a service job category, employees who are able to treated the customer with well-manners such as friendly will be beneficial to the organization (Chua \& Murrmann, 2006). The study also mentioned organization have create their own display rules in order to sustain the emotional labor of employees. A literature review done by Załuski \& Makara-studzińska (2018) which identified emotional labor is an effort to control and regulate employee's emotion in order to meet the expectation of customer and organization. The literature mentioned used of emotional labor at a surface level will lead to difficulties for people to observe the actual feeling as the emotions has been modified according, whereas a deep level will be more into experience the mutual emotion with clients. In order to enhance the understanding of emotional labor strategies in the present study, the definition of each strategy was included at the following (Chua \& Murrmann, 2006). 
Table 1: Conceptual Definition of Emotional Labour Strategies by Chua \& Murrmann (2006)

\begin{tabular}{|c|c|c|}
\hline Strategy & Original Definition & $\begin{array}{l}\text { Simplified } \\
\text { Definition }\end{array}$ \\
\hline $\begin{array}{l}\text { Surface Acting } \\
\text { (SA) }\end{array}$ & $\begin{array}{l}\text { "Employees simulate } \\
\text { emotions that are not } \\
\text { actually felt, by } \\
\text { changing their outward } \\
\text { appearance when } \\
\text { showing required } \\
\text { emotions." }\end{array}$ & $\begin{array}{l}\text { Employee } \\
\text { modified their } \\
\text { emotions \& feeling } \\
\text { which is opposite } \\
\text { their inner feeling } \\
\text { due to job and } \\
\text { organization's } \\
\text { requirements. }\end{array}$ \\
\hline $\begin{array}{l}\text { Deep Acting } \\
\text { (DA) }\end{array}$ & $\begin{array}{l}\text { "Occurs when } \\
\text { employees change not } \\
\text { only their physical } \\
\text { expressions, but also } \\
\text { their inner feelings by } \\
\text { using imagination or } \\
\text { recalling past cheerful } \\
\text { experiences to generate } \\
\text { appropriate positive } \\
\text { emotions." }\end{array}$ & $\begin{array}{l}\quad \text { Employee } \\
\text { modified their } \\
\text { internal feeling and } \\
\text { ensure it aligned } \\
\text { with the job and } \\
\text { organizational } \\
\text { requirements. }\end{array}$ \\
\hline $\begin{array}{l}\text { Genuine Acting } \\
\text { (GA) }\end{array}$ & $\begin{array}{l}\text { "Employees felt } \\
\text { emotions are congruent } \\
\text { with expressed emotion } \\
\text { and display rules." }\end{array}$ & $\begin{array}{l}\text { Employees } \\
\text { display the emotions } \\
\text { and feeling that is } \\
\text { consistent to the job } \\
\text { \& organizational } \\
\text { requirements. }\end{array}$ \\
\hline
\end{tabular}

Emotional labour study have been done in academic context also. Elena \& Mahamad (2014) have conducted research by using qualitative approach. There were about 18 out of 25 response from the academician indicate emotional labour will affect their job performance and satisfaction. The respondent further indicate faking of emotion will impacts to the daily performance. This situation reflects to the definition of Surface Acting which stated in Table 1. Based on the discussion by Panatik et al. (2012) and Lun \& Miu-Chi (2015), satisfaction plays as a role of well-being also.

\section{METHODOLOGY}

\section{Search Strategy}

In order to construct the literature review, the researcher have benchmark numerous literature review by the scholars as a standard to follow (Bulmer, Profetto-mcgrath, \& Cummings, 2009; Gile et al., 2018; (Voegtlin \& Greenwood, 2016). For the very first step, the researcher conducts a broad search through electronic sources such as google (including google scholars), research gate, science direct, emerald insight and other relevant sources which provide research article.

The researcher has used various keywords to search in order to match the context of the study. The key terms that have been search are emotional labour and psychological well-being, emotional labour and employee well-being, emotional labour concept, psychological wellbeing concept, emotional labour and job tenure, emotional labour and demographic profile, emotional labour and teaching professional.

Apart from that, the researcher also included the table to show the article collection from various sources. Table 2 represent the sources where the researcher looks for the article. The total sample article was calculated also $(\mathrm{N}=35)$.

Table 2: Sources for article selection

\begin{tabular}{lc}
\hline \multicolumn{1}{c}{ Sources } & Number of Articles \\
\hline $\begin{array}{l}\text { European Journal of Work and } \\
\text { Organizational Psychology }\end{array}$ & 1 \\
International Journal of Nursing & 1 \\
Studies & \\
Applied Psychology: Health and & 1 \\
Well-Being & 1 \\
Tourism Management & 1 \\
Personality and Individual & 1 \\
Differences & 1 \\
Journal of Organizational Behavior & 28 \\
Journal of Individual Differences & $\mathbf{3 5}$ \\
Others & \multicolumn{1}{c}{ TOTAL }
\end{tabular}

\section{Inclusion/Exclusion Criteria}

The present literature review also consists of inclusion and exclusion criteria during the article sourcing. Studies that met with the following criteria are selected as references for the present literature review:

a) Literature review or conceptual study regarding to emotional labour \& psychological well-being (Bulmer, Profetto-mcgrath, \& Cummings, 2009; Choi \& Kim, 2015; Savoie, 2012; Zapf, 2018)

b) Emotional labour studies that conducted in service sectors, regardless of industry

c) Emotional labour studies that is emphasized on education or academic context (Elena \& Mahamad, 2014; Mahoney, Buboltz, V, \& Doverspike, 2011; Ozturk, Bahcecik, \& Kumral, 2015; Ye \& Chen, 2015; Yin \& Lee, 2012)

d) Emotional labour studies that is emphasized with the effect of job tenure/ years of working experience or other demographic data (Alias, 2017; Isayeva, Yurcu, \& Kasalak, 2017; Dahling \& Perez, 2010; Cheung \& Tang, 2010)

e) The studies instructed in English language

f) The studies that included the research instruments for both emotional labour \& psychological or employee's well-being (Blau, Fertig, \& Park, 2010; Chua \& Murrmann, 2006; Diener et al., 2009; Sandilya \& Shahnawaz, 2018)

g) Prioritize studies from year of 2010 and onwards to obtain the latest information (exception for certain studies that match the context of the research title)

h) Systematic or integrative literature review with human resources related

The exclusion criteria also included in the present literature studies in order to avoid unnecessary data or information which is unreliable and invalid. Following criteria were listed as exclusion criteria for the researcher to exclude the article or database:

a) Thesis or dissertation that is unauthorized or unrecognized

b) Study which instruct in Malay language

c) Study of psychological well-being which is not the outcome measurement 
Table 3: Relationship discussion among variables from previous scholars

\begin{tabular}{|c|c|c|c|}
\hline $\begin{array}{l}\text { Emotional Labour } \\
\text { Strategies }\end{array}$ & Outcomes & Sample Context & References \\
\hline \multirow[t]{6}{*}{ Surface Acting } & $\begin{array}{l}\text { Associate with occupational well-being } \\
\text { (higher job burnout, lower job satisfaction) }\end{array}$ & Teaching professional & (Lun \& Miu-Chi, 2015) \\
\hline & $\begin{array}{l}\text { Shows negative outcome of well-being } \\
\text { among employees }\end{array}$ & - & $\begin{array}{l}\text { (Humphrey, Ashforth, \& } \\
\text { Diefendorff, 2015) }\end{array}$ \\
\hline & $\begin{array}{l}\text { There is correlation between surface acting } \\
\text { and psychological well-being at work }\end{array}$ & Nursing staffs & (Vermaak et al., 2017) \\
\hline & Bring effect to outcomes like job satisfaction & Teachers & (Gillet, Fouquereau, \\
\hline & \& burnout (occupational well-being) & Nursing assistants & $\begin{array}{l}\text { Morin, \& Lapointe, } \\
\text { 2018) }\end{array}$ \\
\hline & $\begin{array}{l}\text { Not related to subjective well-being without } \\
\text { buffer of workplace spirituality }\end{array}$ & Front-line employees & (Zou \& Dahling, 2018) \\
\hline \multirow[t]{4}{*}{ Deep Acting } & $\begin{array}{l}\text { Associate with occupational well-being } \\
\text { (lower job burnout, higher job satisfaction) }\end{array}$ & Teaching professional & (Lun \& Miu-Chi, 2015) \\
\hline & Impact to outcomes such as job satisfaction & Teachers & (Gillet et al., 2018) \\
\hline & \& burnout (occupational well-being) & Nursing assistants & \\
\hline & Positively related to subjective well-being & Front-line employees & (Zou \& Dahling, 2018) \\
\hline $\begin{array}{l}\text { Genuine Acting / } \\
\text { Expression of naturally } \\
\text { felt emotion }\end{array}$ & $\begin{array}{l}\text { Report a better well-being (higher job } \\
\text { burnout, lower job satisfaction) }\end{array}$ & Teaching professional & (Lun \& Miu-Chi, 2015) \\
\hline
\end{tabular}

\section{Selection Strategy}

There were four (4) steps included for selection strategy in terms of article selection which begin from a broader search through electronic database until final selection of the article:

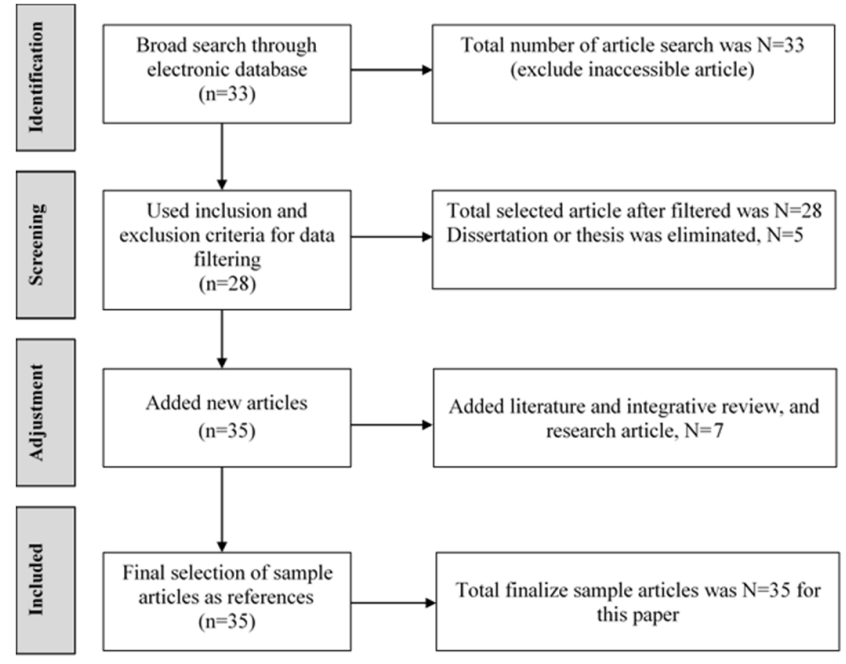

Fig. 4: Flow Diagram for Exclusion \& Inclusion Studies

In total, there were total number of 33 articles being selected for the study. In between, there were five (5) articles being eliminated as those were thesis that have been written the author. As those theses were not considered as reliable information due to unauthorized or accredited by any publisher, thus, the articles were removed from the reference lists.

\section{Data Analysis}

The aim of conducting data analysis was to identify the knowledge in relation to emotional labour, psychological or employee's well- being, and job tenure/working experience in relation to emotional labour. For the first step, all the studies that is related to emotional labour and psychological well-being as outcomes will be included. Based on the previous literature, the predictor of the study, emotional labour strategies will be label and categorized. Most of the scholars identified two (2) common emotional labour strategies, however, few studies also included another strategy as well. Based on the initial studies, there were about three (3) emotional labour strategies for this paper which are as below
a) Surface Acting (SA); and
b) Deep Acting (DA); and
c) Genuine Acting (GA); or
d) Expression of Naturally Felt Emotion (ENFE)

Based on the discussion earlier, though the previous scholar justified there were various dimensions under psychological or employee's well-being, however, the present study will consider psychological or employee's well-being as one (1) main outcome. Various study has proven different emotional labour strategies impact the well-being of employees differently due to study context is different from one to another. As the concept of well-being is wider, the paper will consider the relevant well-being outcomes such as the following:
a) Psychological Well-being; or
b) Subjective Well-being; or
c) Employee Well-being; or
d) Occupational Well-being

The reason is due to different scholars might select different concept of well-being in their study. Thus, a wider view is needed in order to analyse the data.

\section{RESULTS AND DISCUSSION}

\section{Linking Emotional Labour to Well-being of employee}

According to the previous scholars, number of selected articles stated the influence or relationship between emotional labour and employee's well-being in various context: Above table provide a summary result that shows the relationship between emotional labour 
strategies and employee's well-being based on number of previous scholars. It can be observed majority of the study included surface acting and deep acting as the primary emotional labour strategies, however, genuine acting or expression of naturally felt emotion does not study much.lay

\section{Linking Job Tenure to Emotional Labour}

The present study also includes a demographic variable, which is job tenure as demographic variable to identify its effect on emotional labour or vice versa. The table below identify various article that used job tenure or working experience to measure its relationship with emotional labour:

Table 4: Relationship with job tenure and emotional labour from previous studies

\begin{tabular}{llll}
\hline $\begin{array}{l}\text { Demographic } \\
\text { Variable }\end{array}$ & Outcomes & $\begin{array}{l}\text { Sample } \\
\text { context }\end{array}$ & References \\
\hline $\begin{array}{l}\text { Job tenure or } \\
\text { working } \\
\text { experience }\end{array}$ & $\begin{array}{l}\text { Significant } \\
\text { impacts to } \\
\text { emotional }\end{array}$ & $\begin{array}{l}\text { Hotel } \\
\text { employees }\end{array}$ & (Isayeva et al., \\
& $\begin{array}{l}\text { 2017) } \\
\text { labour } \\
\text { Deep acting } \\
\text { and expression } \\
\text { of naturally } \\
\text { felt emotion }\end{array}$ & Nurses & (Alias, 2017) \\
have a & & \\
significant & & \\
& relationship & & \\
& No significant & Nurses & (Kaur, 2019) \\
impacts & & \\
& towards & & \\
& emotional & & \\
labour & & \\
\hline
\end{tabular}

Based on Table 4, it has been identified that job tenure or working experience does not significantly impacts emotional labour in all context. There was a very limited study in assessing relationship between job tenure and emotional labour among the context of academician. Hence, a further study on this particular context is needed to identify the different and contribution to the society.

\section{DISCUSSION}

\section{Emotional Labour and Employee's Well-being}

Previous scholars have completed numerous studies in regards of the relationship between emotional labour and employee's well-being. The present study intends to identify the influence of emotional labour strategies on psychological well-being among academician. As discussed earlier, employee's well-being is one of the key concerns by the organization. Study shows emotional labour bring significant impacts towards psychological well-being among nursing staffs (Vermaak et al., 2017). In addition, nurses who experienced higher level of emotional labour will result in emotional exhaustion which is the burnout factors that is categorized under well-being (Kinman \& Leggetter, 2016). Previous study also identified employees who utilize surface acting (emotional labour strategies) tends to negatively influence their well-being (Humphrey et al., 2015).

Occupation such as teaching profession also encountered the same issues. A research has been conducted at several China's schools founds out teacher who have experienced surface acting will result in high job burnout and lower job satisfaction which are considered as part of occupational well-being (Lun \& Miu-Chi, 2015). The finding was consistent aligned with another study which emotional labor is associate with job satisfaction (Gillet et al., 2018). Research also shows university lecturers performed higher emotional labour (Berry \& Cassidy, 2018). Additionally, educator who engaged in higher education such as college are more likely engaged in automatic acting which is the emotional labour strategies-genuine acting (Hu, Wang, \& Yang, 2017).

The present study aims to study the effect of emotional labour strategies towards the psychological well-being. The study also be moderate by using the demographic profile which is job tenure. The rationale of selecting job tenure for the present study is due to it is one of the key factors that will identify whether job tenure (lengths of service) moderate the emotional labour strategies towards psychological well-being or not. Table below represent the development of variables for the present study:

Table 5: Determinants of variable for the present study

\begin{tabular}{|c|c|c|}
\hline $\begin{array}{l}\text { Types of } \\
\text { Variable }\end{array}$ & Main Variable & Dimensions \\
\hline $\begin{array}{l}\text { Dependent } \\
\text { variable }\end{array}$ & $\begin{array}{l}\text { Psychological } \\
\text { Well-being }\end{array}$ & - \\
\hline $\begin{array}{l}\text { Independent } \\
\text { variable }\end{array}$ & $\begin{array}{l}\text { Emotional Labour } \\
\text { Strategies }\end{array}$ & $\begin{array}{l}\text { Surface Acting } \\
\text { Deep Acting } \\
\text { Genuine Acting / } \\
\text { Expression of } \\
\text { Naturally Felt } \\
\text { Emotion }\end{array}$ \\
\hline Moderator & Job tenure & - \\
\hline
\end{tabular}

As a supporting from the previous scholars to study the relationship between emotional labour strategies and employee's well-being, a research framework have been retrieved from the previous scholars (Bondarenko, Preez, \& Shepherd, 2017). Framework at the following page represent on how organization will enforce emotional labour strategies that impact to employee's well-being:

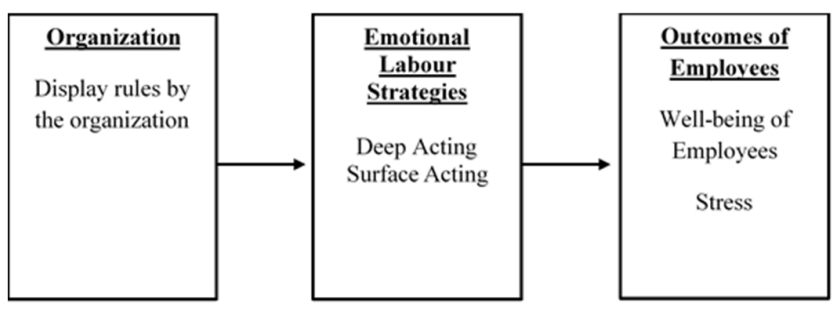

Fig. 5: Organizational display rules towards employees' outcomes by Bondarenko, Preez, \& Shepherd (2017)

As such, the above framework shows the utilization of emotional labour strategies was imposed by the organization which result in wellbeing of the employees. The similarity of the study is found which reflect to the present study, but with different study context such as sample group and/ or additional variables like moderator or mediator.

\section{Emotional Labour \& Demographic Variables}

Apart from dependent and independent variables, the present study has added one demographic profiles, which is job tenure as role of moderator. Studies shows deep acting of nurses associate with higher level of working experience (Alias, 2017). In addition, study in hotel employees also found out deep acting had influence years of experience 
in hotel industry (Isayeva et al., 2017). However, there is also finding have proven working experience of nurses does not influence by emotional labour (Kaur, 2019). This can be explained the inconsistent of finding across various studies could be due to country culture, organizational requirements in terms of emotional displays, personal feeling, sample context and so on.

\section{Research Gap}

Various studies have shown the influence of emotional labour strategies towards employee's psychological well-being. Numerous studies have been done in studying emotional labour in the context of nurses and concluded with different result due to various context and sample group. Generally, nurses are highly engaged in emotional labour as they are highly interacted with patient in the hospital or clinics due to demand of patient is different. Based on the discussion earlier, hotels employees have been selected as frequent sample to study in emotional labour context. This is due to interaction with guests required emotional labour strategies like deep acting or genuine acting.

On the other hand, education setting is also an important area to be study for the investigation of emotional labour. Studies also shown emotional labour effect impact to education or academic job setting. However, the setting of studies is less likely found in Malaysia context. In addition, though Malaysia university has been selected in one of the scholar's studies, yet, there is no specification which public universities of Malaysia has been selected. The previous study also does not completely find an association between emotional labour strategies and psychological well-being with job tenure or working experience as moderator. Thus, this shown a research gap in between and needed to be further study. As such, the present study has proposed to identify the influence of emotional labour strategies which job tenure plays as moderator towards psychological well-being of academician among public universities in Malaysia.

\section{LIMITATION}

This systematic literature review provides an insight in terms of emotional labour strategies towards employee's well-being. Though previous scholars have identified the impacts of emotional labours towards well-being of employees, however, there are still limited finding in terms of specific context that study on academician public university and in Malaysia. Apart from that, another difficulty for the paper was demographic variable like job tenure or working experience has limited finding as well. Database accessibility have also limited the researcher for further study due to unauthorized personnel to access the article. At last, researcher find difficulties in terms of standardized the systematic literature review writing method as per scholars due to different study context and dimensions.

\section{CONCLUSION}

In a nutshell, this paper aims to identify the influence of emotional labour strategies towards psychological well-being among academicians with job tenure as moderator. Though the literature review has completed with a body of knowledge from the previous scholars, however, the actual finding is yet to completed. The knowledge of emotional labour is important, especially for service employees like academician, who are required to have high interaction with students from different background, demand, expectation and so on, which in turn impacts their well-being. As such, this paper will fill the research gap by identifying how both variables significant with the moderator of job tenure.

\section{REFERENCES}

Alias, R. (2017). Exploring the Relationship between Demographic Variables and Emotional Labour Strategies in Health Care. Aryabhatta Journal of Mathematics and Informatics, 09(01), 94-102.

Berry, K., \& Cassidy, S. (2018). Emotional Labour in University Lecturers : Considerations for Higher Education Emotional Labour in University Lecturers : Considerations for Higher Education Institutions, (April). https://doi.org/10.5430/jct.v2n2p22

Blau, G., Fertig, J., \& Park, D. S. (2010). Further scale refinement for emotional labor Exploring distinctions between types of surface versus deep acting using a difficult client referent. Career Development International, 15(February), 188-216. https://doi.org/10.1108/13620431011040969

Bondarenko, Y., Preez, E., \& Shepherd, D. (2017). Emotional Labour in Mental Health Field Workers. New Zealand Journal of Psychology, 46(1), 4 13

Bulmer, K., Profetto-mcgrath, J., \& Cummings, G. G. (2009). Emotional intelligence and nursing: An integrative literature review. International Journal of Nursing Studies, 46, 1624-1636. https://doi.org/10.1016/j.ijnurstu.2009.05.024

Cheung, F. Y., \& Tang, C. S. (2010). Effects of Age, Gender, and Emotional Labor Strategies on Job Outcomes: Moderated Mediation Analyses Effects of Age, Gender, and Emotional Labor Strategies on Job Outcomes: Moderated. APPLIED PSYCHOLOGY: HEALTH AND WELL-BEING, 2 (3)(September 2010), 323-339. https://doi.org/10.1111/j.1758-0854.2010.01037.x

Choi, Y., \& Kim, K. (2015). A Literature Review of Emotional Labor and Emotional Labor Strategies. Universal Journal of Management, 3(7), 283-290. https://doi.org/10.13189/ujm.2015.030704

Chua, K. H.-L., \& Murrmann, S. K. (2006). Development and validation of the hospitality emotional labor scale. Tourism Management, 27, 1181-1191. https://doi.org/10.1016/j.tourman.2005.12.011

Dahling, J. J., \& Perez, L. A. (2010). Older worker, different actor? Linking age and emotional labor strategies. Personality and Individual Differences, 48, 574-578. https://doi.org/10.1016/j.paid.2009.12.009

Diener, E., Wirtz, D., Biswas-diener, R., Tov, W., Kim-prieto, C., Choi, D., \& Oishi, S. (2009). New Measures of Well-Being. https://doi.org/10.1007/978-90-481-2354-4

Dierendonck, D. van, Dı'az, D., Amalio, B., Rodri'guez-Carvajal, R., \& Moreno-Jime'nez, B. (2007). Ryff' s Six-factor Model of Psychological Well-being, A Spanish Exploration. Social Indicator Research, 87(June 2014), 473-479. https://doi.org/10.1007/s11205-007-9174-7

Elena, T., \& Mahamad, T. (2014). Understanding and Managing Malaysian Academics ' Emotional Labour. International Proceedings of Economics Development and Research (IPEDR), 70(2005), 76-80. https://doi.org/10.7763/IPEDR.

Gile, P. P., Buljac-samardzic, M., \& Klundert, J. Van De. (2018). The effect of human resource management on performance in hospitals in SubSaharan Africa : a systematic literature review. Human Resources for Health, 1-21.

Gillet, N., Fouquereau, E., Morin, A. J. S., \& Lapointe, É. (2018). Emotional labour profiles: Associations with key predictors and outcomes Work \& Stress Emotional labour profiles : Associations with key predictors and $\begin{array}{lllll}\text { outcomes. Work \& } & \text { Stress, } & 0(0), & 1-27\end{array}$ https://doi.org/10.1080/02678373.2018.1502835

Hu, Q., Wang, C., \& Yang, X. (2017). The Relationship between Emotional Labor and Mental Health of College Teachers : the Mediate Effect of Emotional Exhaustion. 4th International Conference on Advanced Education and Management, (Icaem), 515-522.

Humphrey, R. H., Ashforth, B. E., \& Diefendorff, J. M. (2015). The bright side of emotional labor. Journal of Organizational Behavior, 769(May 2015), 749-769. https://doi.org/10.1002/job

Isayeva, S., Yurcu, G., \& Kasalak, M. A. (2017). Investigation of Emotional Labor Levels of Hotel Employees in Terms of Demographic Variables. Journal of Tourism \& Hospitality, 6(6), 1-8. https://doi.org/10.4172/2167-0269.1000322

Jayasinghe, C. (2017). A Model of Employee Well-being for Front-line Employees in Hotel Industry. International Journal of Scientific and Research Publications, 7(5), 60-64.

Kaur, S. (2019). Influence of Emotional Labour on Burnout among Nurses : A Sem Approach. Journal of Quality in Health Care \& Economics, 2(1), $1-10$.

Kinman, G., \& Leggetter, S. (2016). Emotional Labour and Wellbeing: What Protects Nurses? Healthcare, 4, 1-12. https://doi.org/10.3390/healthcare4040089

Lun, F. C., \& Miu-Chi, V. (2015). Emotional Labor and Occupational Well- 
Being. Journal of Individual Differences, 36(February 2015), 30-37. https://doi.org/10.1027/1614-0001/a000152

Mahoney, K. T., Buboltz, W. C., V, J. E. B., \& Doverspike, D. (2011). Emotional Labor in American Professors, 16(4), 406-423. https://doi.org/10.1037/a0025099

Ozturk, H., Bahcecik, N., \& Kumral, S. (2015). Emotional Labor Levels Of Nurse Academicians. In Procedia - Social and Behavioral Sciences (Vol. 190, pp. 32-38). https://doi.org/10.1016/j.sbspro.2015.04.912

Panatik, S. A. B., Rajab, A., Roziana, S., Shah Mad, I., Abdul Rahman, H., \& Badri, S. K. B. Z. (2012). Impact of Work-related Stress on Well-being among Academician in Malaysian Research University. International Conference on Education and Management Innovation, 30, 37-41.

Page, K. M., \& Vella-brodrick, D. (2014). The 'What', 'Why' and 'How' of Employee Well-Being: A New Model. Social Indicator Research, 90(September), 441-458. https://doi.org/10.1007/s11205-008-9270-3

Peiro, J. M., Tordera, N., \& Lorente, L. (2014). Sustainable well-being at work: a review and reformulation. Papeles Del Psicólogo, 35 (1)(January), 514.

Sandilya, G., \& Shahnawaz, G. (2018). Index of Psychological Well-being at Work-Validation of Tool in the Indian Organizational Context. The Journal of Business Perspective, 22 (2)(April), 1-12. https://doi.org/10.1177/0972262918766134

Savoie, V. D.-D. • A. (2012). What is Psychological Well-Being, Really? A Grassroots Approach from the Organizational Sciences What is Psychological Well-Being, Really? A Grassroots Approach from the Organizational Sciences. Journal of Happiness Studies, (August 2012). https://doi.org/10.1007/s10902-011-9285-3

Vermaak, C., Görgens-ekermans, G., \& Nieuwenhuize, C. (2017). SHIFT WORK, EMOTIONAL LABOUR AND PSYCHOLOGICAL WELLBEING OF NURSING STAFF. Journal of Contemporary Management Issues, 22, 35-48.

Voegtlin, C., \& Greenwood, M. (2016). Corporate social responsibility and human resource management: A systematic review and conceptual analysis. Human Resource Management Review, 26(3), 181-197. https://doi.org/10.1016/j.hrmr.2015.12.003

Ye, M., \& Chen, Y. (2015). A Literature Review on Teachers 'Emotional Labor. Creative Education, 6(November), 2232-2240.

Yin, H., \& Lee, J. C. (2012). Be passionate, but be rational as well: Emotional rules for Chinese teachers' work. Teaching and Teacher Education, 28, 56-65. https://doi.org/10.1016/j.tate.2011.08.005

Załuski, M., \& Makara-studzińska, M. (2018). Emotional labour in medical professions. Review of literature from the period 2010-2017. Medical Communication, 18(2), 194-199. https://doi.org/10.15557/PiPK.2018.0023

Zapf, D. (2018). Emotion work and psychological well-being A review of the literature and some conceptual considerations. Human Resource Management Review, 12(January 2002), 237-268.

Zou, W., \& Dahling, J. (2018). Workplace spirituality buffers the effects of emotional labour on employee well-being. European Journal of Work and Organizational Psychology, $00(00), \quad 1-10$. https://doi.org/10.1080/1359432X.2017.1358164 